\title{
Fermentative hydrogen production using pretreated microalgal biomass as feedstock
}

\author{
Jianlong Wang ${ }^{1,2^{*}}$ and Yanan Yin ${ }^{1}$
}

\begin{abstract}
Microalgae are simple chlorophyll containing organisms, they have high photosynthetic efficiency and can synthesize and accumulate large quantities of carbohydrate biomass. They can be cultivated in fresh water, seawater and wastewater. They have been used as feedstock for producing biodiesel, bioethanol and biogas. The production of these biofuels can be integrated with $\mathrm{CO}_{2}$ mitigation, wastewater treatment, and the production of high-value chemicals. Biohydrogen from microalgae is renewable. Microalgae have several advantages compared to terrestrial plants, such as higher growth rate with superior $\mathrm{CO}_{2}$ fixation capacity; they do not need arable land to grow; they do not contain lignin. In this review, the biology of microalgae and the chemical composition of microalgae were briefly introduced, the advantages and disadvantages of hydrogen production from microalgae were discussed, and the pretreatment of microalgal biomass and the fermentative hydrogen production from microalgal biomass pretreated by different methods (including physical, chemical, biological and combined methods) were summarized and evaluated. For the production of biohydrogen from microalgae, the economic feasibility remains the most important aspect to consider. Several technological and economic issues must be addressed to achieve success on a commercial scale.
\end{abstract}

Keywords: Microalgae, Biohydrogen, Pretreatment, Fermentation

\section{Background}

The fossil fuels are depleting and resulting in serious environment issues. Hydrogen gas is regarded as a potential candidate for a future energy economy. Hydrogen is the only carbon-free fuel, with water as its final combustion product. Therefore the application of hydrogen will greatly contribute to the reduction of the energy-related environmental issues, such as greenhouse emission or acid rain $[1,2]$.

Biohydrogen is defined as hydrogen produced biologically, most commonly by algae, bacteria and archaea from both cultivation and from waste organic materials [3]. Most biologically produced hydrogen in the biosphere is evolved in microbial fermentation processes. These organisms decompose organic matter to carbon dioxide and hydrogen.

\footnotetext{
*Correspondence: wangj@@tsinghua.edu.cn

${ }^{1}$ Collaborative Innovation Center for Advanced Nuclear Energy Technology, INET, Energy Science Building, Tsinghua University, Beijing 100084, People's Republic of China

Full list of author information is available at the end of the article
}

Microalgal biomass, being rich in carbohydrates, has great potential as feedstock for the production of various biofuels such as biodiesel, bioethanol, biohydrogen and biogas (Fig. 1), in an economically effective and environmentally friendly way [4]. Microalgae are a high-potential source of biomass for the production of food, industrial materials, pharmaceuticals and energy [5].

Microalgae like cyanobacteria and green algae can produce biohydrogen after derivation of their photosynthetic metabolism. Besides, microalgae can also be used as feedstock for biohydrogen production by microbial dark fermentation.

Biohydrogen from microalgae is renewable. The production of biohydrogen by microalgae through photofermentation is of interest, because it generates hydrogen gas from the most plentiful resources, light and water. However, the adaptation of the algae to an anaerobic atmosphere is prerequisite. Unfortunately, hydrogen production by this process is quite ineffective since the simultaneously produced oxygen would inhibit the hydrogenase enzyme. Therefore, accumulation of oxygen will stop the hydrogen production process. 


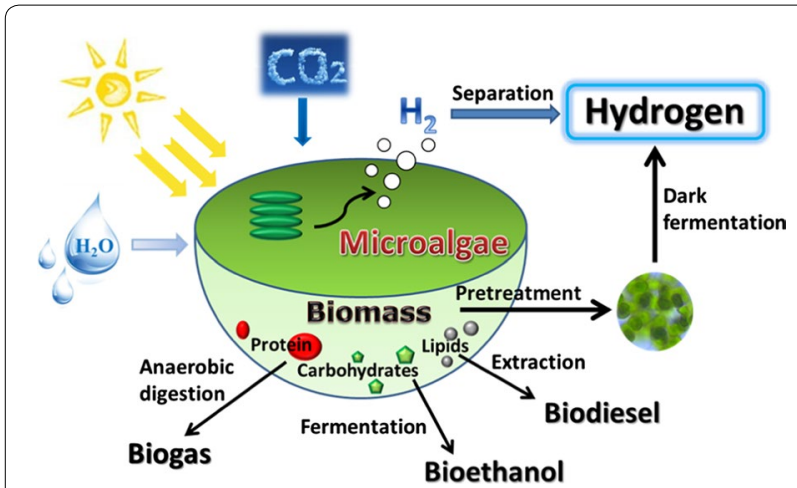

Fig. 1 Potential pathways from microalgae to biofuels

The production of biohydrogen from microalgae through dark fermentation has received increasing attention in recent years [6]. However, biohydrogen potentials are usually low and a pretreatment step is often required to convert polymeric carbohydrates into monomeric sugars, to increase the microbial accessibility and further the biohydrogen production. Thus, physical, chemical and biological pretreatments are usually employed in order to facilitate carbohydrates de-polymerization and enhance biohydrogen production from microalgae.

The present mini-review will briefly introduce the biohydrogen production from microalgal biomass through dark fermentation, focusing on the pretreatments of microalgae to enhance hydrogen production.

\section{Biology of microalgae}

Microalgae in this review refer to all microscopic oxygenic phototrophs. Microalgae are primitive plant, which are one of the oldest life forms on earth. They are lack of roots, stems and leaves, have chlorophyll a as their primary photosynthetic pigment. Microalgae are commonly photosynthetic organisms that primarily use water, carbon dioxide, and sunlight to produce biomass and oxygen (Fig. 2).

Microalgae are a diverse group of prokaryotic and eukaryotic photosynthetic microorganisms, which are normally found in marine and freshwater habitats. They can be grouped into prokaryotic microalgae (Cyanobacteria), eukaryotic microalgae (green algae Chlorophyta), red algae (Rhodophyta), and diatoms (Bacillariophyta), which are capable of growing rapidly due to their low nutrient requirement and simple structure. Besides to natural environments, microalgae can be cultivated in freshwater, seawater, and wastewater within open ponds (raceway) and closed photo-bioreactors.

Microalgae structures are primarily for energy conversion, and their simple development makes them to adapt to prevailing environmental conditions.

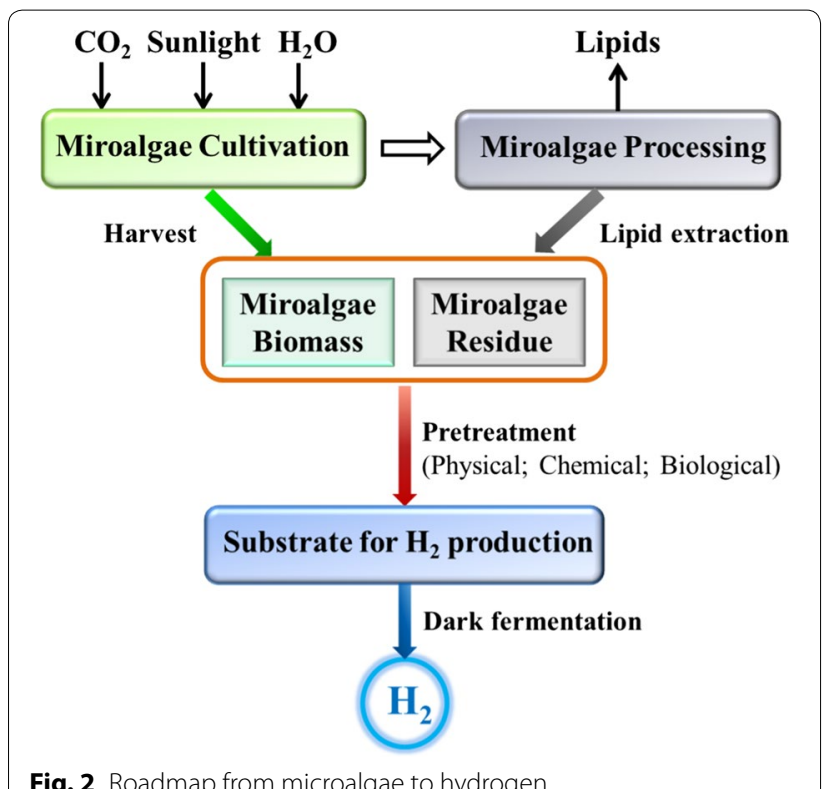

Fig. 2 Roadmap from microalgae to hydrogen

Microalgae are autotrophic, heterotrophic and mixotrophic. The autotrophic algae require only inorganic carbon source such as $\mathrm{CO}_{2}$, salts and a light energy source for growth; while the heterotrophic ones are non-photosynthetic, they require an external source of organic compounds as an energy source; the mixotrophic algae are capable of performing photosynthesis and acquiring exogenous organic nutrients. For autotrophic algae, photosynthesis is a key component of their survival, whereby they convert solar light and $\mathrm{CO}_{2}$ into adenosine triphosphate (ATP) and $\mathrm{O}_{2}$, which is then used in respiration to produce energy to support growth.

\section{Microalgal chemical composition}

Components of microalgae vary according to their species and cultivation environment. Microalgae contain approximately $50 \%$ carbon by dry weight, which is typically derived from carbon dioxide. Production of $100 \mathrm{~g}$ of microalgal biomass can fix about $183 \mathrm{~g}$ of carbon dioxide.

In terms of chemical composition, microalgal biomass is mainly composed of proteins, carbohydrates and lipids. In general, proteins account for $40-60 \%$ of dry biomass, followed by carbohydrate (20-30\%) and lipids (10-20\%). Table 1 presents the general compositions of different microalgae [7-9].

Table 1 shows that the distribution of biochemical fractions of a microalgae cell is as follows: proteins $28-71 \%$, carbohydrates $10-57 \%$, lipids $4-22 \%$. It is worth noting that the figures presented in Table 1 are estimates, since the proportion of individual cell constituents largely depends on environmental parameters. The chemical 
Table 1 General composition of different microalgae (\% of dry matter)

\begin{tabular}{llll}
\hline Microalgae & Protein & Carbohydrate & Lipid \\
\hline Anabaena cylindrica & $43-56$ & $25-30$ & $4-7$ \\
Chlamydomonas reinhardtii & 48 & 17 & 21 \\
Chlorella vulgaris & $51-58$ & $12-17$ & $14-22$ \\
Dunaliella salina & 57 & 32 & 6 \\
Porphyridium cruentum & $28-39$ & $40-57$ & $9-14$ \\
Scenedesmus obliquus & $50-56$ & $10-17$ & $12-14$ \\
Spirulina maxima & $60-71$ & $13-16$ & $6-7$ \\
Synechococcus sp. & 63 & 15 & 11 \\
\hline
\end{tabular}

composition of microalgae is high variable, largely depending on species, environmental conditions and cultivation methods. For instance, nutritional limitation and deprivation can induce and maximize lipid and carbohydrates synthesis by changing the metabolic strategies of microalgae. Microalgal cells tend to synthesize lipid instead of the starch at nitrogen-limited and high light conditions. In addition to these three major components, microalgal cells also contain small amount of nucleic acids (1-5\%), and other valuable components (foe example, pigments, anti-oxidants, fatty acids and vitamins) [10-14].

\section{Advantages and disadvantages of hydrogen production from microalgae}

The components of microalgae are valuable for a wide range of applications. Carbohydrates in microalgae can exist in the form of glucose and some polysaccharides like starch, agar, carrageenan, etc., which are considered to be an appropriate feedstock for generation of various fermentation products. Algal lipids are composed of glycerol, sugars or bases esterified to saturated or unsaturated fatty acids, which can be used for biodiesel production. The related long-chain fatty acids, pigments, and proteins have their own nutraceutical and pharmaceutical applications.

Comparing with the cellulose-based biomass and waste activated sludge produced from wastewater treatment plant, microalgae are a relatively new energy source. They have many advantages, for example, they have high growth rate with the fixation of $\mathrm{CO}_{2}$, cultivation of microalgae can be beneficial to the environment by combining with wastewater treatment, they can be easily used as substrate with high carbohydrate content and simple structure and so on (Table 2) [7, 9, 10, 14].

One of the major disadvantages of microalgae for biohydrogen production is the low biomass concentration in the microalgal culture due to the limit of light penetration, which in combination with the small size of algal cells makes the harvest of algal biomass relatively costly. The large water content of harvested algal biomass also means its drying would be an energy-consuming process. The higher capital costs and the rather intensive care required by a microalgal farming facility compared to a conventional agricultural farm is another factor that impedes the commercial implementation of the biofuels from microalgae strategy.

Nevertheless, these problems are expected to be overcome or minimized by technology development. Given the vast potential of microalgae as the most efficient primary producers of biomass, there is little doubt that they will eventually become one of the most important alternative energy sources.

\section{Pretreatment of microalgal biomass}

Since the hydrolytic enzymatic activity of hydrogenproducing bacteria is usually low, in order to enhance the biohydrogen production efficiency of fermentation process, the pretreatment step is often required for the hydrolysis of algal biomass to release the organic substances from the algal cells and make them readily biodegraded. A variety of pretreatment technologies that are researched and developed for treating other waste materials (e.g., animal waste and municipal sewage sludge) can be used to pretreat microalgal biomass for biohydrogen production.

Pretreatment methods can be divided into four categories: physical (mechanical, heat and ultrasonic treatment), chemical (acid, base and ozone), biological (enzymatic and microbiological treatment) and a combination of different treatments.

The most commonly used for pretreatment of microalgae to enhance carbohydrates hydrolysis include milling, ultrasonic, microwave, steam explosion, chemical oxidation and enzymatic hydrolysis.

In fact, the objective of all these pretreatment methods is the disruption of the cell wall to release the organic substances from the cells. Therefore they are applicable to biohydrogen production.

\section{Hydrogen production from microalgae}

Microalgae have been used as feedstock for producing biodiesel, bioethanol and biogas. Various microbial species have been used as feedstock for biohydrogen production, among which Chlorella sp., Scenedesmus sp. and Saccharina sp. have been extensively studied. To enhance the hydrogen production efficiency, different pretreatment methods were explored. 
Table 2 Advantages and disadvantages of microalgae as feedstock for biohydrogen production

\begin{tabular}{|c|c|}
\hline Advantages & Disadvantages \\
\hline 1. High growth rate & 1. Low biomass concentration \\
\hline $\begin{array}{l}\text { Microalgae can proliferate rapidly and are capable of all year round } \\
\text { production, and be obtained in large amount easily, which makes it } \\
\text { possible to satisfy the massive demand on biofuels using limited land } \\
\text { resources without causing potential biomass deficit. Their exponential } \\
\text { growth rates can double their biomass in periods as short as } 3.5 \mathrm{~h}\end{array}$ & $\begin{array}{l}\text { The low biomass concentration in the microalgal culture, in combination } \\
\text { with the small size of algal cells, makes the harvest of algal biomasses } \\
\text { relatively costly }\end{array}$ \\
\hline 2. Superior $\mathrm{CO}_{2}$ fixation capacity & 2. Large water content \\
\hline $\begin{array}{l}\text { Microalgae are quite efficient in utilizing inorganic carbon sources to } \\
\text { synthesize cell biomass, and their tolerance to high } \mathrm{CO}_{2} \text { content in gas } \\
\text { streams allows high-efficiency } \mathrm{CO}_{2} \text { mitigation ( } 1 \mathrm{~kg} \text { of dry algal biomass } \\
\text { utilize about } 1.83 \mathrm{~kg} \text { of }\left(\mathrm{CO}_{2}\right)\end{array}$ & $\begin{array}{l}\text { The large water content of harvested algal biomass suggests that its drying } \\
\text { process would be energy-consuming }\end{array}$ \\
\hline 3. Benefit to the environment & 3. Higher capital cost \\
\hline $\begin{array}{l}\text { The cultivation of microalgae does not require herbicides or pesticides } \\
\text { application. Nitrous oxide release could be minimized when they are } \\
\text { used for biofuel production }\end{array}$ & $\begin{array}{l}\text { The higher capital costs and the rather intensive care required by } \\
\text { microalgal cultivation facility compared to a conventional agricultural } \\
\text { farm would impede the commercial application of the biofuels from } \\
\text { microalgae }\end{array}$ \\
\hline \multicolumn{2}{|l|}{ 4. Strong adaptation to environment } \\
\hline \multicolumn{2}{|l|}{$\begin{array}{l}\text { Microalgae have strong adaptation to various environments without } \\
\text { competing with fertile soils for agriculture }\end{array}$} \\
\hline \multicolumn{2}{|l|}{ 5. Growth in aqueous media, less water required } \\
\hline \multicolumn{2}{|l|}{$\begin{array}{l}\text { Microalgae do not need arable land to grow, they grow in aqueous } \\
\text { media, therefore may not incur land-use change, minimizing the associ- } \\
\text { ated environmental impacts, and their cultivation consumes less water } \\
\text { than terrestrial crops, thus reducing the load on freshwater sources }\end{array}$} \\
\hline \multicolumn{2}{|l|}{ 6. High carbohydrate content } \\
\hline \multicolumn{2}{|l|}{$\begin{array}{l}\text { Microalgae have high carbohydrate content, which is helpful in enhanc- } \\
\text { ing the hydrogen production efficiency }\end{array}$} \\
\hline \multicolumn{2}{|l|}{ 7. Simple structure } \\
\hline \multicolumn{2}{|l|}{$\begin{array}{l}\text { Microalgae are lack of hemicellulose and lignin, thus, the required pre- } \\
\text { treatments can be milder }\end{array}$} \\
\hline \multicolumn{2}{|l|}{ 8. Easy cultivation } \\
\hline $\begin{array}{l}\text { Microalgae are unicellular or simple-multicellular microorganisms, which } \\
\text { are adaptive to various environment conditions, and can be cultivated } \\
\text { in fresh water, seawater and wastewater. The biochemical composition } \\
\text { of the algal biomass can be modulated by varying growth conditions. } \\
\text { The nutrients for microalgae cultivation (especially nitrogen and phos- } \\
\text { phorus) can be obtained from wastewater. Therefore, apart from provid- } \\
\text { ing growth medium, there is dual potential for treatment of wastewater }\end{array}$ & \\
\hline
\end{tabular}

Hydrogen production from un-pretreated microalgae

Table 3 summarizes the hydrogen production from microalgae without pretreatment. It can be seen that Chlorella vulgaris is the most widely used as substrate for hydrogen production without treatment. Hydrogen yield obtained ranges from 0.37 to $19 \mathrm{~mL} \mathrm{H}_{2} / \mathrm{g}$ VS, and highest hydrogen yield was achieved from C. vulgaris [15], followed by the lipid extracted Scenedesmus sp. [16].

\section{Hydrogen production from physically and chemically pretreated microalgae}

The physical and chemical pretreatments, including mechanical, heat, ultrasonic, acid, base and ozonation, have been widely applied to disrupt and disintegrate the cell wall of microalgal biomass for enhancing the subsequent biological conversion process. For example,
Ortigueira et al. [24] investigated fermentative hydrogen production using dry ground Scenedesmus obliquus biomass as feedstock. Usually, the use of microalgae biomass as a fermentable feedstock is determined by the recovery of the intracellular sugars and those that constitute the cell walls. Thermal pretreatment normally involves some additional pretreatment. For instance, when increasing temperature by autoclaving or microwaving, side pretreatments such as pressure build-up or electromagnetic radiation, respectively, will also have an effect on pretreated biomass. Chemical pretreatment of different types of wastes was shown to improve hydrogen production.

Table 4 summarizes the hydrogen production from microalgae pretreated by physical and chemical 
Wang and Yin Microb Cell Fact (2018) 17:22

Page 5 of 16

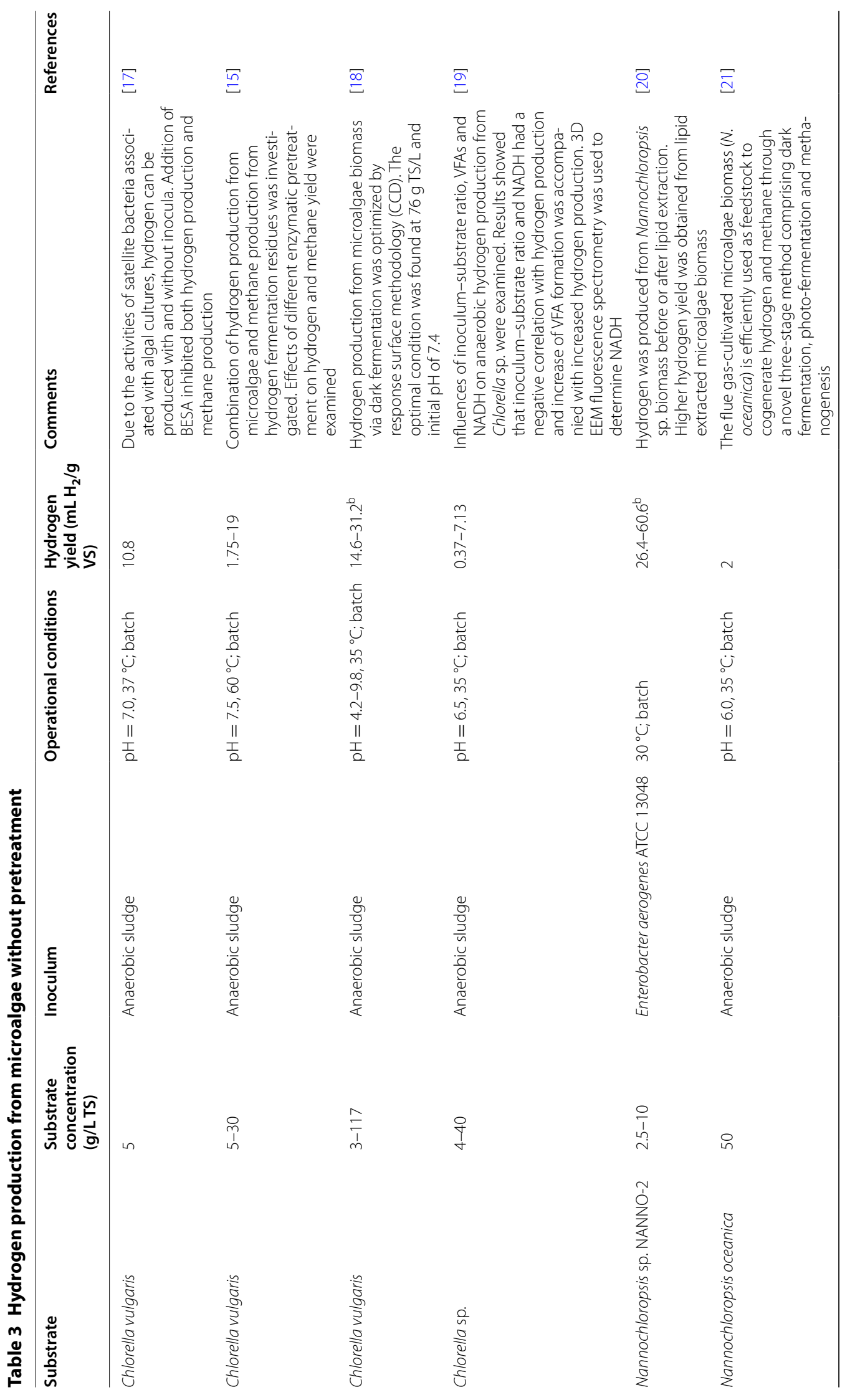




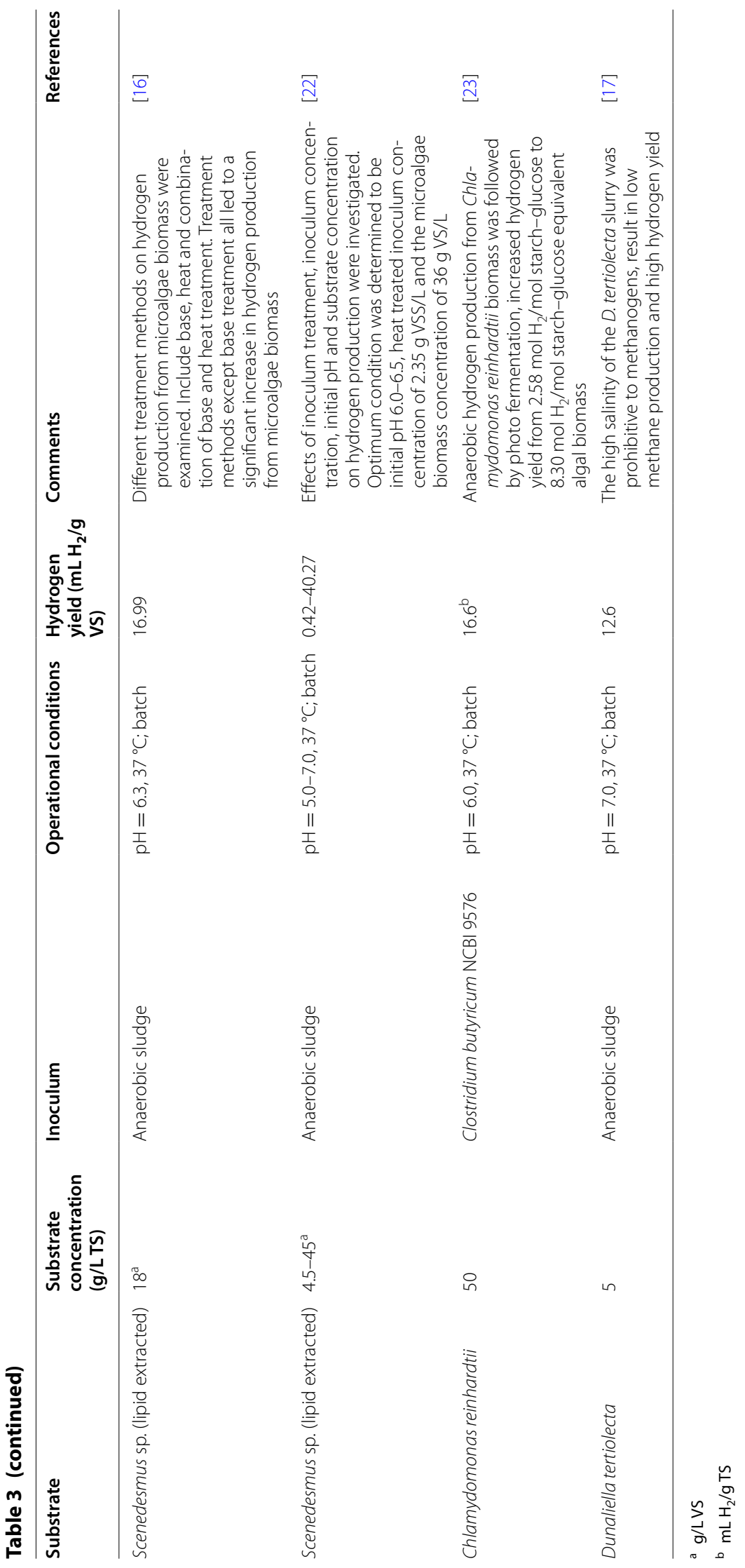




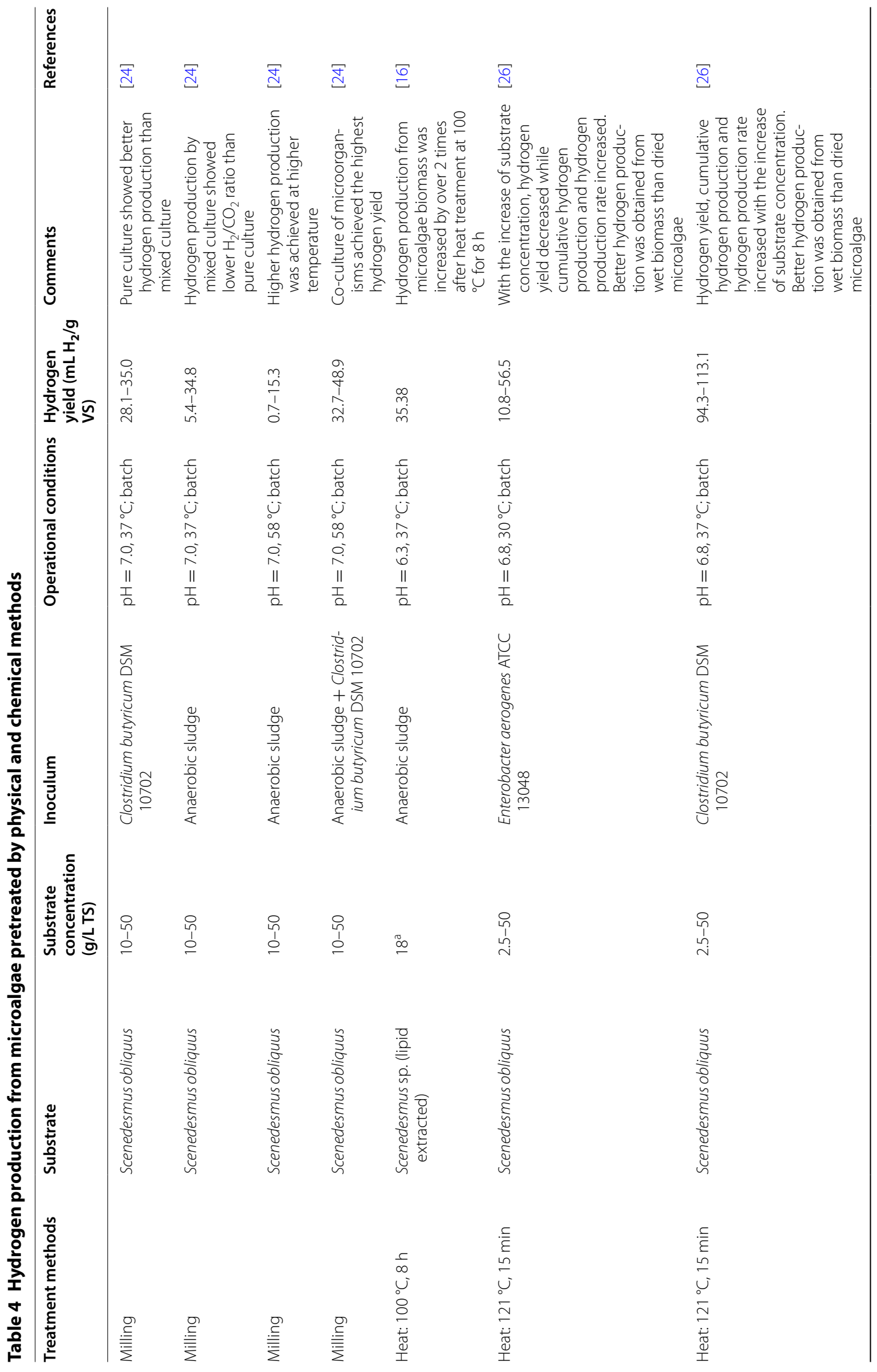


Wang and Yin Microbe Cell Fact (2018) 17:22

Page 8 of 16

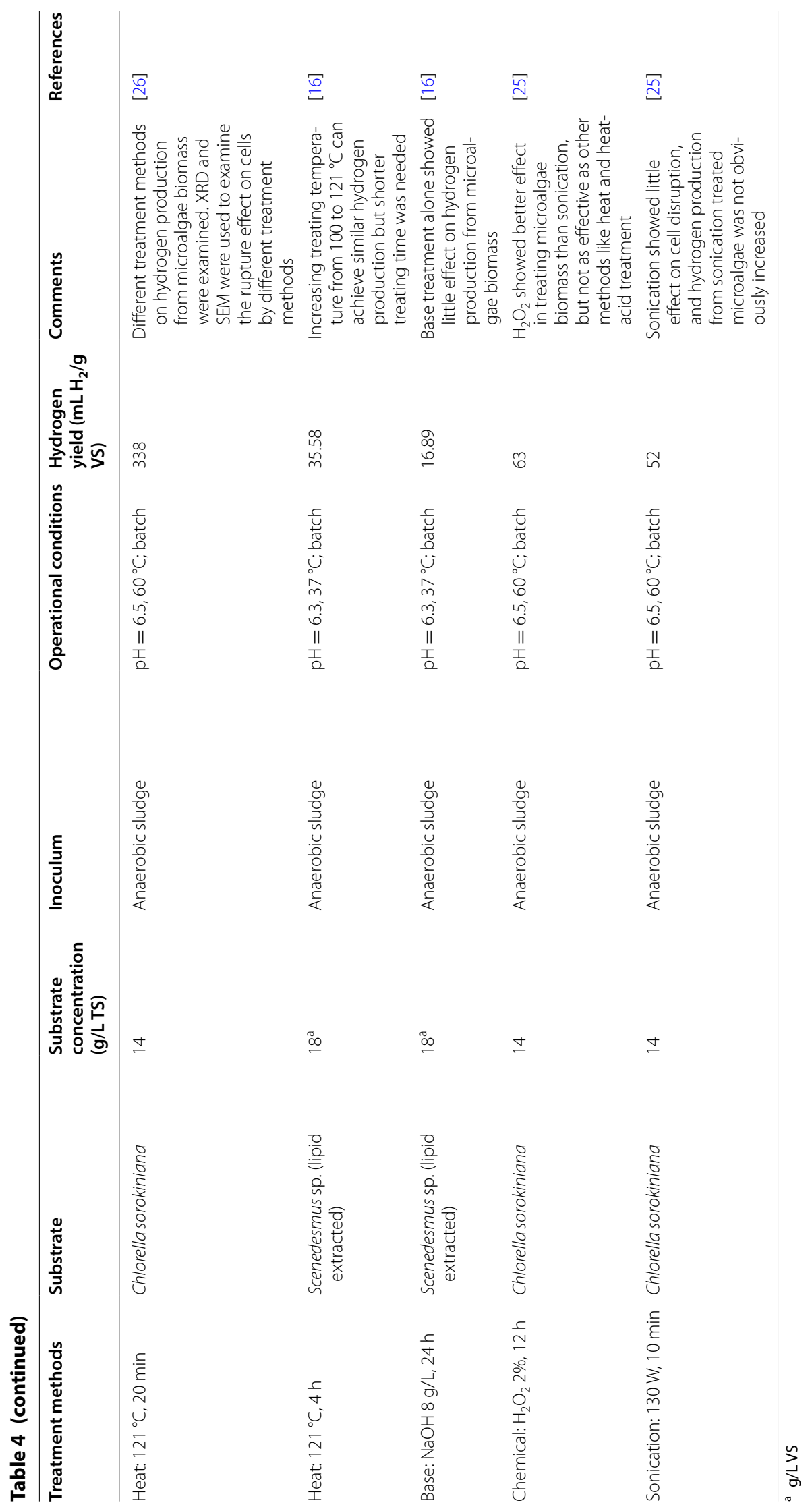


methods. It can be seen that hydrogen yield obtained from the physically and chemically treated microalgae were obviously higher than microalgae without treatment, indicating that both physical and chemical treatment can help to disrupt the microalgal cell. Relatively higher hydrogen yield was obtained from the heat treated microalgae $\left(94.3-338 \mathrm{~mL} \mathrm{H}_{2} / \mathrm{g} \mathrm{VS}\right)$ and highest hydrogen yield was obtained from the heat treated Chlorella sorokiniana [25].

\section{Hydrogen production from biologically pretreated microalgae}

The biological approaches use microbes and enzymes to disrupt biomass and release intracellular materials, which enhances the biohydrogen production rate. Depending on cell wall composition, enzymes election is crucial. Additionally, $\mathrm{pH}$, temperatures, and the microalgae/ enzyme ratio are important parameters to control during enzymatic treatment. The electrostatic bind enzymemicroalgae are affected by acid or alkali conditions. Under inappropriate $\mathrm{pH}$ conditions, enzymes can even be inactivated by denaturing. Similarly, higher temperature results in increasing interactions enzyme-microalgae until a certain level at which denaturalization may happen. Finally, the enzyme/microalgae ratio influences the enzyme activity efficiency. High loading of microalgae may result in high viscosity due to the release of insoluble matter which in turn can hinder enzymatic activity.

Composition of microalgae cell walls include cellulose, mucopolysaccharide and peptidoglycan, etc., therefore research on microalgal biomass focus on the application of macerozyme. Cellulases were proven to be suitable for disruption of C. sorokiniana cell wall, and lysozyme was found to be able to dissolve Cyanobacteria cell wall. Cell wall lysis was supported by microscopic observation.

Table 5 summarizes the hydrogen production from microalgae pretreated by biological method. It can be seen that hydrogen yield varies greatly in the range of 11-135 $\mathrm{mL} \mathrm{H}_{2} / \mathrm{g}$ VS. Higher hydrogen yield was obtained by enzyme treated microalgae than microbial consortium treated microalgae, and a combination of different enzymes can significant enhance the hydrogen yield [15].

\section{Hydrogen production from microalgae pretreated by combined methods}

To disintegrate biomass more efficiently and to take advantage of various pretreatment methods, the combination of different pretreatment methods has been used. Most combined pretreatment methods comprise a physical treatment method and a chemical treatment method.

Combined heat and acid pretreatment is the most commonly used method. Besides acid pretreatment, heat pretreatment has also been combined with other methods such as base pretreatment, enzymatic treatment and oxidizing agent addition. Other combination of pretreatment methods has been also applied, such as combining ozone with ultrasonication and enzyme hydrolysis, respectively; combining microwave with base and acid pretreatment, respectively; combining ionizing radiation and base pretreatment. All of them achieved enhanced hydrogen production from pretreated biomass wastes. In some cases, combinations of three or more pretreatment methods were also used, such as acid-heat-enzyme pretreatment $[28,29]$, acid-microwave-enzyme pretreatment [30], base-heat-enzyme pretreatment [31] and so on.

Table 6 summarized the hydrogen production from microalgae pretreated by the combined methods. It can be seen that the hydrogen yield varies in the range of $33.56-958 \mathrm{~mL} \mathrm{H}_{2} / \mathrm{g}$ VS. The combination of acid and heat showed the highest potential in enhancing the hydrogen production from microalgae, and Chlorella sp. are more preferable in achieving higher hydrogen yield.

\section{Concluding remarks and perspectives}

Microalgae are capable of producing high levels of carbohydrates such as starch or cellulose as reserve materials, which are ideal feedstocks for hydrogen production. Microalgae can potentially be employed for the production of biohydrogen in an economically affective and environmentally sustainable manner. The production of biohydrogen from microalgae can be integrated with flue gas $\left(\mathrm{CO}_{2}\right)$ mitigation, wastewater treatment, and the production of high-value chemicals. There is increasing interest in using microalgae as the renewable feedstock for the production of biohydrogen. In comparison with terrestrial biofuel feedstocks, microalgae can convert solar energy into fuels with higher photosynthetic efficiency, can synthesize and accumulate large quantities of carbohydrate biomass, and can thrive in seawater system.

Studies have shown that fermentative hydrogen production from microalgae shows great potential in sustainable energy generation. Hydrogen production can be modified through disrupting the microalgal cells by some pretreatment methods, and a proper combination of different treatment methods can achieve a synergistic effect and thus significantly enhance the hydrogen yield.

However, there still remain some obstacles hindering the wide application of hydrogen production from microalgae, and several technological and economic issues must be addressed to achieve success on a commercial scale. Studies have shown great variance in the hydrogen yield, some of the hydrogen yields are high, like 958 and $760 \mathrm{~mL} \mathrm{H}_{2} / \mathrm{g}$ VS obtained from acid-heat treated $C$. sorokiniana while some are far from industrial application. Thus, further studies are needed to enhance the cost effectiveness of the biohydrogen from microalgae, like 
Wang and Yin Microbe Cell Fact (2018) 17:22

Page 10 of 16

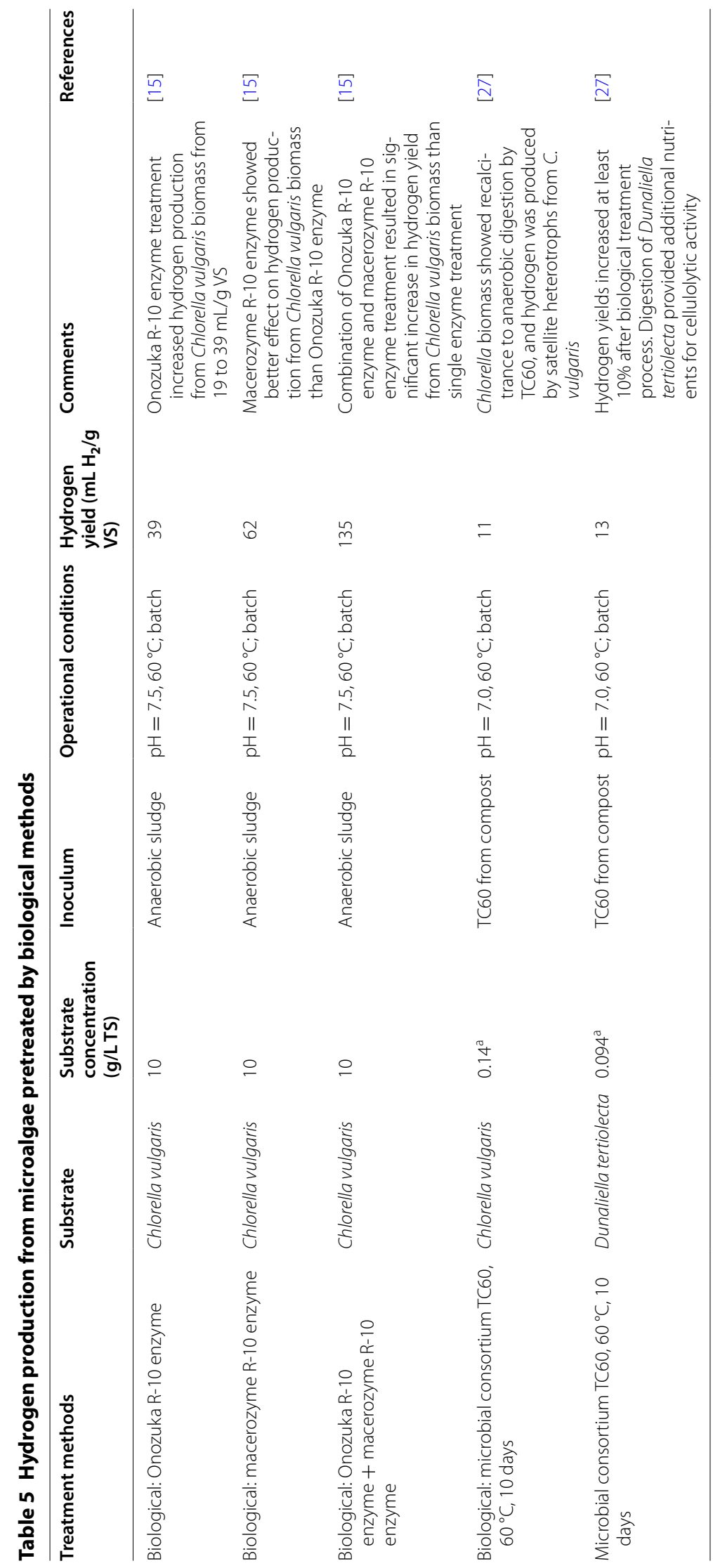


Wang and Yin Microb Cell Fact (2018) 17:22

Page 11 of 16

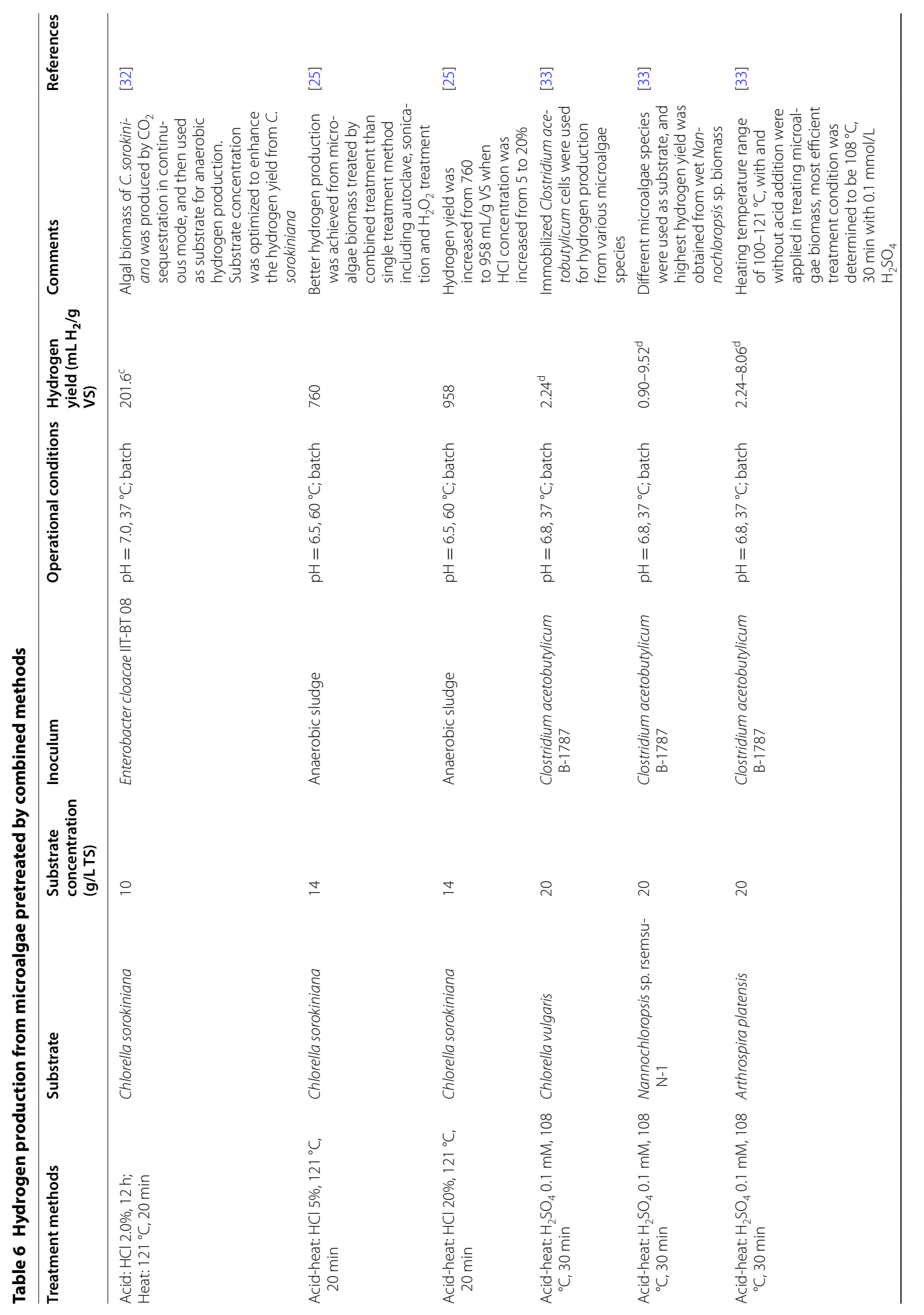




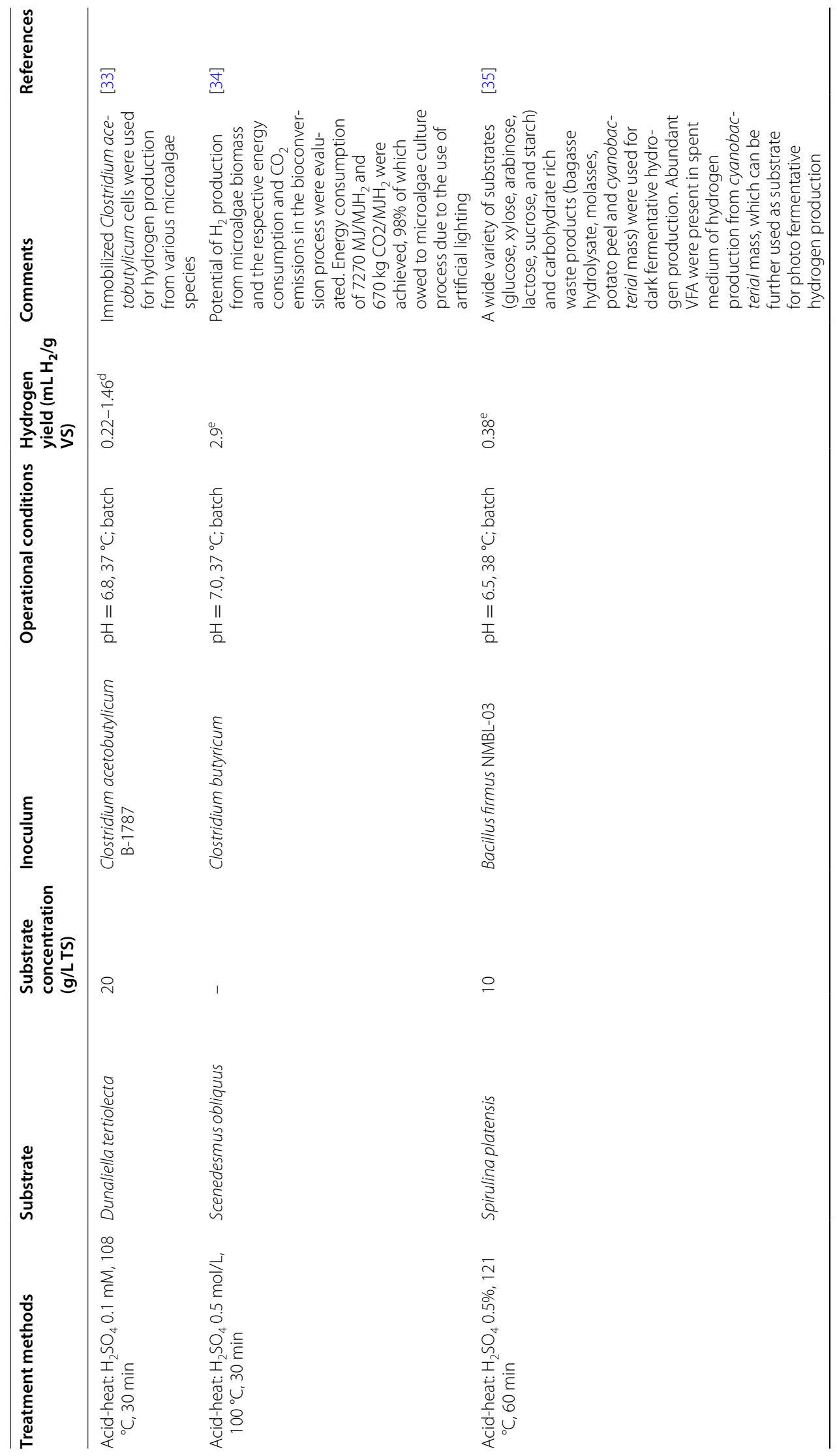




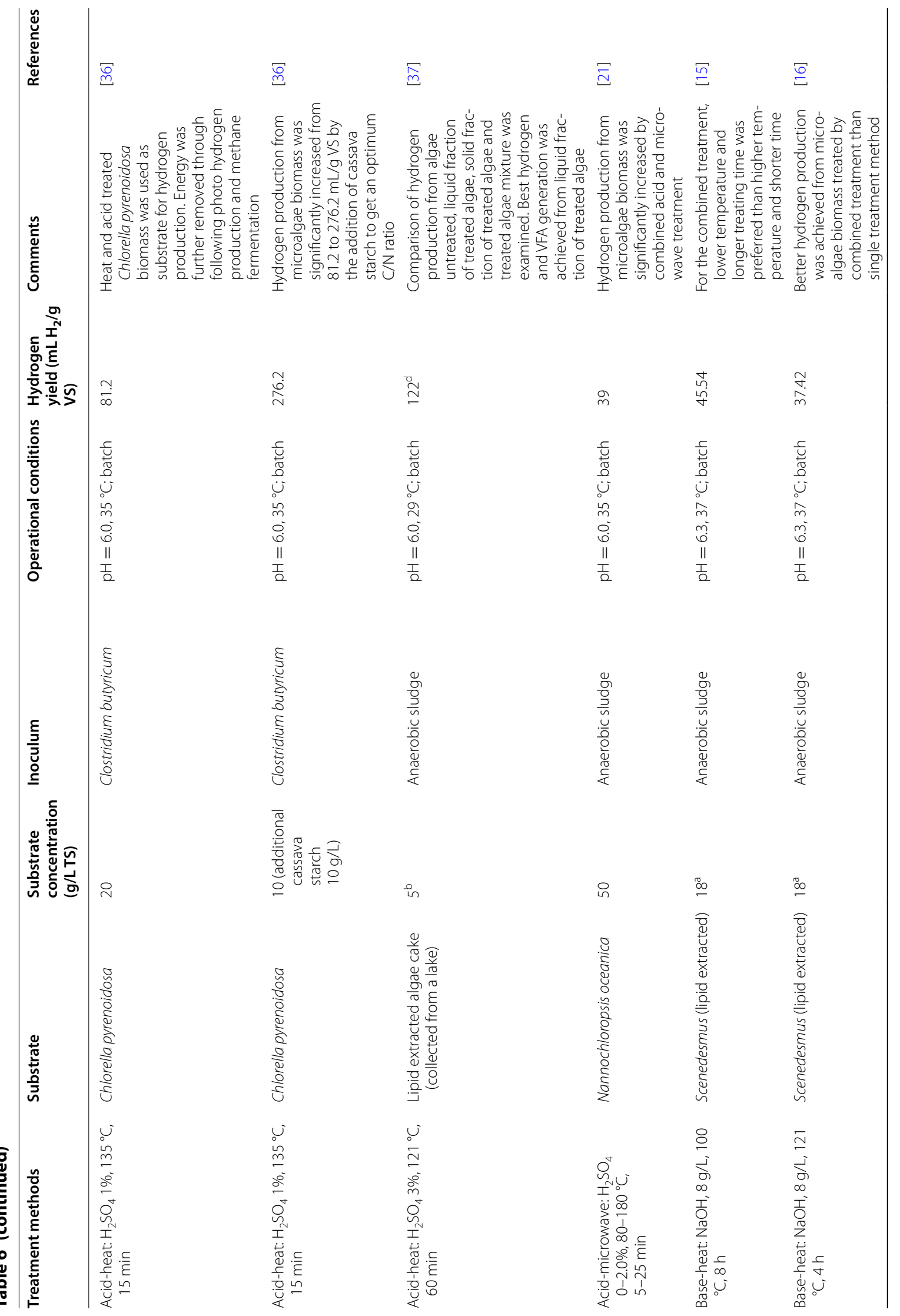




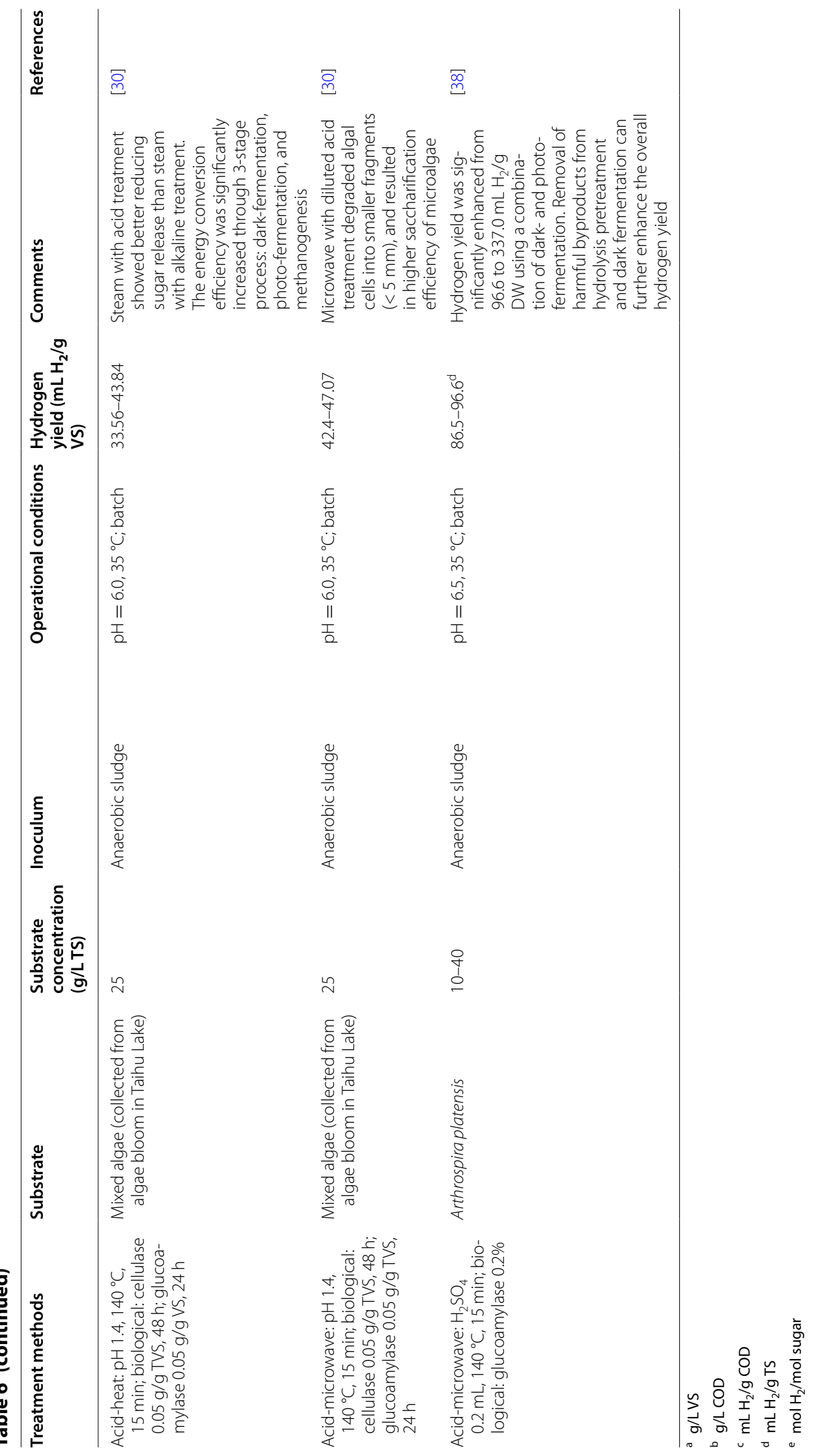


the improvement in microalgal cultivation and downstream processing (e.g., harvesting, concentrating and drying), optimization of nutritional structure of microalgae for hydrogen production through adding protein-rich or mineral nutrient-rich wastes, operational conditions optimization including inoculum, initial $\mathrm{pH}$, temperature as well as reactor structure, etc.

\section{Authors' contributions}

YY has collected the literatures and drawn figures. JW finished the writing of this paper. Both authors read and approved the final manuscript.

\begin{abstract}
Author details
${ }^{1}$ Collaborative Innovation Center for Advanced Nuclear Energy Technology, INET, Energy Science Building, Tsinghua University, Beijing 100084, People's Republic of China. ${ }^{2}$ Beijing Key Laboratory of Radioactive Waste Treatment, Tsinghua University, Beijing 100084, People's Republic of China.
\end{abstract}

\section{Acknowledgements}

The research was supported by the National Natural Science Foundation of China (51338005) and the Program for Changjiang Scholars and Innovative Research Team in University (IRT-13026).

\section{Competing interests}

The authors declare that they have no competing interests.

\section{Availability of data and materials}

This is a review paper and did not deal with this issue.

\section{Consent for publication}

All authors agree to its submission and publication to Microbial Cell Factories.

\section{Ethics approval and consent to participate}

There is no ethics involved in this review paper.

\section{Publisher's Note}

Springer Nature remains neutral with regard to jurisdictional claims in published maps and institutional affiliations.

\section{Received: 2 November 2017 Accepted: 9 February 2018}

Published online: 14 February 2018

\section{References}

1. Yin YN, Wang JL. Biohydrogen production using waste activated sludge disintegrated by gamma irradiation. Appl Energy. 2015;155:434-9.

2. Wang JL, Yin YN. Biohydrogen production from organic wastes. Singapore: Springer; 2017. https://doi.org/10.1007/978-981-10-4675-9.

3. Wang $J$ L, Wan W. Factors influencing fermentative hydrogen production: a review. Int J Hydrogen Energy. 2009;34(2):799-811.

4. Sambusiti C, Bellucci M, Zabaniotou A, Beneduce L, Monlau F. Algae as promising feedstocks for fermentative biohydrogen production according to a biorefinery approach: a comprehensive review. Renew Sustain Energy Rev. 2015;44:20-36.

5. Kondaveeti S, Choi KS, Kakarla R, Min B. Microalgae Scenedesmus obliquus as renewable biomass feedstock for electricity generation in microbial fuel cells (MFCs). Front Environ Sci Eng. 2014;8(5):784-91.

6. Rajhi H, Puyol D, Martinez MC, Diaz EE, Sanz JL. Vacuum promotes metabolic shifts and increases biogenic hydrogen production in dark fermentation systems. Front Environ Sci Eng. 2016;10(3):513-21.

7. Luque R. Algal biofuels: the eternal promise? Energy Environ Sci. 2010;3(3):254-7.

8. Becker EW. Microalgae: biotechnology and microbiology, vol. 10. Cambridge: Cambridge University Press; 1994.

9. Uggetti E, Sialve B, Trably E, Steyer JP. Integrating microalgae production with anaerobic digestion: a biorefinery approach. Biofuels Bioprod Biorefin. 2014:8(4):516-29.
10. Misra N, Panda PK, Parida BK, Mishra BK. Way forward to achieve sustainable and cost-effective biofuel production from microalgae: a review. Int J Environ Sci Technol. 2016;13(11):2735-56.

11. Lakaniemi A, Tuovinen OH, Puhakka JA. Anaerobic conversion of microalgal biomass to sustainable energy carriers - a review. Bioresour Technol. 2013;135:222-31

12. Villarruel-Lopez A, Ascencio F, Nuno K. Microalgae, a potential natural functional food source_-a review. Pol J Food Nutr Sci. 2017;67(4):251-63.

13. Hu JJ, Nagarajan D, Zhang OG, Chang J, Lee D. Heterotrophic cultivation of microalgae for pigment production: a review. Biotechnol Adv. 2018;36(1):54-67.

14. Zhan J, Zhang Q, Qin M, Hong Y. Selection and characterization of eight freshwater green algae strains for synchronous water purification and lipid production. Front Environ Sci Eng. 2016;10(3):548-58.

15. Wieczorek N, Kucuker MA, Kuchta K. Fermentative hydrogen and methane production from microalgal biomass (Chlorella vulgaris) in a two-stage combined process. Appl Energy. 2014;132:108-17.

16. Yang ZM, Guo RB, Xu XH, Fan XL, Li XP. Enhanced hydrogen production from lipid-extracted microalgal biomass residues through pretreatment. Int J Hydrogen Energy. 2010;35(18):9618-23.

17. Lakaniemi A, Hulatt CJ, Thomas DN, Tuovinen OH, Puhakka JA. Biogenic hydrogen and methane production from Chlorella vulgaris and Dunaliella tertiolecta biomass. Biotechnol Biofuels. 2011;4(1):1.

18. Yun YM, Jung KW, Kim DH, Oh YK, Shin HS. Microalgal biomass as a feedstock for bio-hydrogen production. Int J Hydrogen Energy. 2012;37(20):15533-9.

19. Sun JX, Yuan XZ, Shi XS, Chu CF, Guo RB, Kong HN. Fermentation of Chlorella sp. for anaerobic bio-hydrogen production: influences of inoculum-substrate ratio, volatile fatty acids and NADH. Bioresour Technol. 2011;102(22):10480-5.

20. Nobre BP, Villalobos F, Barragán BE, Oliveira AC, Batista AP, Marques PASS, Mendes RL, Sovová H, Palavra AF, Gouveia L. A biorefinery from Nannochloropsis sp. microalga-extraction of oils and pigments. Production of biohydrogen from the leftover biomass. Bioresour Technol. 2013;135:128-36

21. Xia A, Cheng J, Lin RC, Lu HX, Zhou JH, Cen KF. Comparison in dark hydrogen fermentation followed by photo hydrogen fermentation and methanogenesis between protein and carbohydrate compositions in Nannochloropsis oceanica biomass. Bioresour Technol. 2013;138:204-13.

22. Yang ZM, Guo RB, Xu XH, Fan XL, Luo SJ. Fermentative hydrogen production from lipid-extracted microalgal biomass residues. Appl Energy. 2011:88(10SI):3468-72.

23. Kim MS, Baek JS, Yun YS, Junsim SJ, Park S, Kim SC. Hydrogen production from Chlamydomonas reinhardtii biomass using a two-step conversion process: anaerobic conversion and photosynthetic fermentation. Int J Hydrogen Energy. 2006;31(6):812-6.

24. Ortigueira J, Alves L, Gouveia L, Moura P. Third generation biohydrogen production by Clostridium butyricum and adapted mixed cultures from Scenedesmus obliquus microalga biomass. Fuel. 2015;153:128-34.

25. Roy S, Kumar K, Ghosh S, Das D. Thermophilic biohydrogen production using pre-treated algal biomass as substrate. Biomass Bioenergy. 2014;61:157-66.

26. Batista AP, Moura P, Marques PASS, Ortiqueira J, Alves L, Gouveia L. Scenedesmus obliquus as feedstock for biohydrogen production by Enterobacter aerogenes and Clostridium butyricum. Fuel. 2014;117(Part A):537-43.

27. Carver SM, Hulatt CJ, Thomas DN, Tuovinen $\mathrm{OH}$. Thermophilic, anaerobic co-digestion of microalgal biomass and cellulose for $\mathrm{H}_{2}$ production. Biodegradation. 2011;22(4):805-14.

28. Wang $Y$, Wang $H$, Feng $X Q$, Wang $X F$, Huang JX. Biohydrogen production from cornstalk wastes by anaerobic fermentation with activated sludge. Int J Hydrogen Energy. 2010;35(7):3092-9.

29. Kumar G, Sen B, Sivagurunathan P, Lin C. High rate hydrogen fermentation of cello-lignin fraction in de-oiled jatropha waste using hybrid immobilized cell system. Fuel. 2016;182:131-40.

30. Cheng J, Liu YQ Lin RC, Xia A, Zhou JH, Cen KF. Cogeneration of hydrogen and methane from the pretreated biomass of algae bloom in Taihu Lake. Int J Hydrogen Energy. 2014;39(33):18793-802.

31. Phummala K, Imai T, Reungsang A, Chairattanamanokorn P, Sekine M, Higuchi T, Yamamoto K, Kanno A. Delignification of disposable wooden 
chopsticks waste for fermentative hydrogen production by an enriched culture from a hot spring. J Environ Sci. 2014;26:1361-8.

32. Kumar K, Roy S, Das D. Continuous mode of carbon dioxide sequestration by C. sorokiniana and subsequent use of its biomass for hydrogen production by E. cloacae IIT-BT 08. Bioresour Technol. 2013;145:116-22.

33. Efremenko EN, Nikolskaya AB, Lyagin IV, Senko OV, Makhlis TA, Stepanov NA, Maslova OV, Mamedova F, Varfolomeev SD. Production of biofuels from pretreated microalgae biomass by anaerobic fermentation with immobilized Clostridium acetobutylicum cells. Bioresour Technol. 2012;114:342-8

34. Ferreira AF, Ortigueira J, Alves L, Gouveia L, Moura P, Silva CM. Energy requirement and $\mathrm{CO}_{2}$ emissions of bio $\mathrm{H}_{2}$ production from microalgal biomass. Biomass Bioenergy. 2013:49:249-59.
35. Sinha P, Pandey A. Biohydrogen production from various feedstocks by Bacillus firmus NMBL-03. Int J Hydrogen Energy. 2014;39(14):7518-25.

36. Xia A, Cheng J, Ding LK, Lin RC, Song WL, Zhou JH, Cen KF. Enhancement of energy production efficiency from mixed biomass of Chlorella pyrenoidosa and cassava starch through combined hydrogen fermentation and methanogenesis. Appl Energy. 2014;120:23-30.

37. Subhash GV, Mohan SV. Deoiled algal cake as feedstock for dark fermentative biohydrogen production: an integrated biorefinery approach. Int J Hydrogen Energy. 2014;39(18):9573-9.

38. Cheng J, Xia A, Liu Y, Lin R, Zhou J, Cen K. Combination of dark- and photo-fermentation to improve hydrogen production from Arthrospira platensis wet biomass with ammonium removal by zeolite. Int J Hydrogen Energy. 2012;37(18):13330-7.

\section{Submit your next manuscript to BioMed Central and we will help you at every step:}

- We accept pre-submission inquiries

- Our selector tool helps you to find the most relevant journal

- We provide round the clock customer support

- Convenient online submission

- Thorough peer review

- Inclusion in PubMed and all major indexing services

- Maximum visibility for your research

Submit your manuscript at www.biomedcentral com/submit 